\title{
GENETIC CONTROL OF COMMON BEAN (Phaseolus vulgaris) RESISTANCE TO POWDERY MILDEW (Erysiphe polygoni)
}

\author{
Viviane Ferreira Rezende, Magno Antonio Patto Ramalho and Hercules Renato Corte
}

\begin{abstract}
Genetic control of common bean (Phaseolus vulgaris) resistance to powdery mildew (Erysiphe polygoni) was studied using segregating populations from the bean variety crosses Jalo $\times$ ESAL 686 and ESAL $550 \times$ ESAL 686. $F_{2}$ plants, together with the parents, were inoculated and evaluated using a scale of values from one (plant without symptoms) to nine (completely infected plant). $F_{2}$ plants were harvested individually, and $F_{2: 3}$ families were obtained. These families were evaluated in an 11 x 11 and $12 \times 12$ simple lattice statistical design for the Jalo x ESAL 686 and ESAL 550 x ESAL 686 crosses, respectively, using the same value scale as the $F_{2}$ generation. The segregation observed in $F_{2}$ plants and $F_{2: 3}$ families indicated that two genes are involved in genetic control, due to a double recessive epistasis. The high linear regression coefficient (b) between $\mathrm{F}_{2}$ plants and their $\mathrm{F}_{2: 3}$ family, 0.66 for ESAL $550 \times$ ESAL 686 cross, and 0.71 for Jalo $\times$ ESAL 686 cross, showed that the trait is highly heritable.
\end{abstract}

\section{INTRODUCTION}

Powdery mildew disease is considered to be of secondary importance in the common bean (Sartorato and Rava, 1994). However, with the increase of bean sowing in the fall-winter, when conditions favor the occurrence of the causative organism, Erysiphe polygoni (family Erysiphaceae, order Erysiphales), an increase in the importance of this pathogen is expected. Powdery mildew can cause extensive losses in grain productivity (Schwartz et al., 1981; Arriel et al., 1991).

Although chemical products are efficient control alternatives (Rava and Sartorato, 1993), the main solution adopted is the use of resistant cultivars. There are several reports of cultivars with a good level of resistance to the pathogen (Schwartz et al., 1981; Sartorato et al., 1983; Sartorato et al., 1993). However, most of the resistant cultivars have medium to small-sized grains and indeterminate growth habits. One of the few cultivars with large grains, determinate habit and resistance is the line ESAL 686 (Rezende et al., 1996).

Large grain cultivars are usually incompatible with small grain cultivars (Singh and Gutierrez, 1984; Vieira et al., 1989), making it difficult to incorporate resistance into large grained cultivars. The resistance found in the large grain ESAL 686 lineage (Rezende et al., 1996) could facilitate breeding new cultivars with large grains and resistance to the powdery mildew pathogen. A study was made of the genetic control of resistance in ESAL 686, to determine resistance to Erysiphe polygoni in segregating populations.

Departamento de Biologia, Universidade Federal de Lavras, Caixa Postal 37, 37200-000 Lavras, MG, Brasil. Send correspondence to M.A.P.R.

\section{MATERIAL AND METHODS}

The susceptible parent lines used were Jalo and ESAL 550, with indeterminate growth habits, and the resistant ESAL 686, with determinate growth habit, both with large yellow grains. The study was carried out from 1995 to 1997 at Federal University of Lavras in Southern Minas Gerais State (21 14' S, 45 00' W, 900 m above sea level), on a dusky red latosol (oxisol), climate $\mathrm{CWb}$, according to the climatic classification of Koppen (Ometto, 1981).

$\mathrm{F}_{2}$ plants, together with the parents, were sown in the field and inoculated with the pathogen by the contact of pieces of infected leaves with healthy leaves (Rezende et al., 1996). Evaluations were made close to harvest time, using a scale of one to nine (Table I).

Table I - Scale of values used to evaluate the reaction of common bean (Phaseolus vulgaris) lines to Erysiphe polygoni.

\begin{tabular}{|cc|}
\hline Values & Infected foliar area $(\boldsymbol{\%})$ \\
\hline 1 & 0 \\
2 & 1 \\
3 & 1 to 5 \\
4 & 5 to 10 \\
5 & 10 to 20 \\
6 & 20 to 40 \\
7 & 40 to 60 \\
8 & 60 to 80 \\
9 & 80 to 100 \\
\hline
\end{tabular}

$\mathrm{F}_{2}$ plants were harvested individually, and $\mathrm{F}_{2: 3}$ families were obtained. In the case of the ESAL $550 \times$ ESAL 686 cross, 144 families were evaluated, using a 12 x 12 simple lattice statistical design. In Jalo x ESAL 686, 121 families were evaluated in an 11 x 11 simple lattice design. Additionally, the parents were sown as a control in all blocks. Each plot consisted of a one-meter line with 15 seeds. Fifteen days before the experiment, the susceptible 
cultivar Jalo was sown around the experimental area. Twenty days after sowing, plants were inoculated using the same procedure used for $\mathrm{F}_{2}$ plants.

Families were evaluated for powdery mildew close to harvest time by three evaluators. The average values given by the three evaluators were subjected to analysis of variance and the genetic and phenotypic parameters were estimated, using a methodology similar to that presented by Ramalho et al. (1993). The linear regression coefficient (b) between $\mathrm{F}_{2}$ plant performance and its $\mathrm{F}_{2: 3}$ families (Nyquist, 1991) was estimated.

\section{RESULTS AND DISCUSSION}

Pathogen pressure was intense, making it possible to cleanly discriminate plant reaction types during evaluation of symptoms. The ESAL 686 line confirmed the previously reported resistance to this pathogen (Rezende et $a l ., 1996)$ while the other parents were found highly susceptible.

A major difficulty in this type of study is to define resistant versus susceptible lines. Bett and Michaels (1995), in a study of genetic control of resistance to powdery mildew in Mexico, considered plants resistant when they received values of zero or one, on a scale of zero to four. The same procedure was adopted by Dundas (1936). In our work, the scale varied from one to nine and plants with values of four or less were considered resistant. However, visual evaluation can vary from one cross to another. In addition, pathogen incidence itself can vary among the crosses and even within the same cross from one generation to another. Therefore, we made an adjustment of the values given to the two generations of the two crosses, considering that discrepancies occurred in the average of the values found (Table II). This adjustment was made by correction factors. These factors were obtained by dividing the mean value obtained in the evaluations of each generation and cross by that obtained in the $\mathrm{F}_{2}$ generation of the ESAL $550 \times$ ESAL 686 cross. Each value was multiplied by the correction factor so that in all cases the average of the values was the same. The frequency distributions were obtained in this manner (Figure 1).

Considering the performance of $\mathrm{F}_{2}$ plants, the segregation observed fits nine resistant:seven susceptible in both crosses (Table III), indicating that two interacting genes are involved in controlling the trait. This is a case of double recessive epistasis (Ramalho et al., 1994), that is, the plant will only be resistant if it possesses dominant alleles of both genes involved.

Evaluations of the $\mathrm{F}_{2: 3}$ families confirmed the results obtained with the $\mathrm{F}_{2}$ plants. A summary of the analysis of variance values (Table II) shows that efficiency of the lattice statistical design was lower than $1 \%$. This indicates that heterogeneity did not occur in the pathogen distribution among the blocks within the same repetition. The experimental precision evaluated by the variation coefficient can be considered good. Considering the large number of families evaluated, a certain discrepancy was expected in the values given by the evaluators to the same family in the two repetitions. The value frequency distribution of the $\mathrm{F}_{2: 3}$ families, after making the adjustments mentioned, confirms that the segregation observed was nine resistant to seven susceptible (Table III).

The segregation observed in this study contrasts with that reported by Dundas (1936), who found the trait to be controlled by one gene, resistance being due to a dominant allele. On the other hand, Bett and Michaels (1995) also report the occurrence of two genes. In one case resistance was dominant and, in the other, recessive. The discrepancy in these results can be attributed to the difference in genetic constitution of the parents involved in each case. Furthermore, evaluation of resistance to the pathogen through a scale of values can vary depending on the evaluators.

Table II - Summary of the analysis of variance of values for Erysiphe polygoni occurrence in family evaluations of $\mathrm{F}_{2.3}$ generation of Phaseolus vulgaris ESAL 550 x ESAL 686 and Jalo x ESAL 686 crosses.

\begin{tabular}{|c|c|c|c|c|}
\hline \multirow[b]{2}{*}{ Source of variation } & \multicolumn{2}{|c|}{ ESAL $550 \times$ ESAL 686} & \multicolumn{2}{|c|}{ Jalo x ESAL 686} \\
\hline & d.f. & Mean square & d.f. & Mean square \\
\hline Replications & 1 & 0.292 & 1 & 1.851 \\
\hline Adjusted treatments & 143 & $8.740 *$ & 120 & $8.713 *$ \\
\hline Effective error & 121 & 1.101 & 100 & 1.191 \\
\hline Lattice efficiency & & 100.07 & & 100.96 \\
\hline C.V. (\%) & & 20.33 & & 23.10 \\
\hline Heritability (\%) & & 87.40 & & 86.33 \\
\hline Regression coefficent $(b$ & & & & \\
\hline $\mathrm{F}_{2}$ plant and $\mathrm{F}_{2.3}$ family & & 0.66 & & 0.71 \\
\hline Average & & 5.16 & & 4.72 \\
\hline
\end{tabular}

*Significant at 0.01 probability level by F-test. 
A

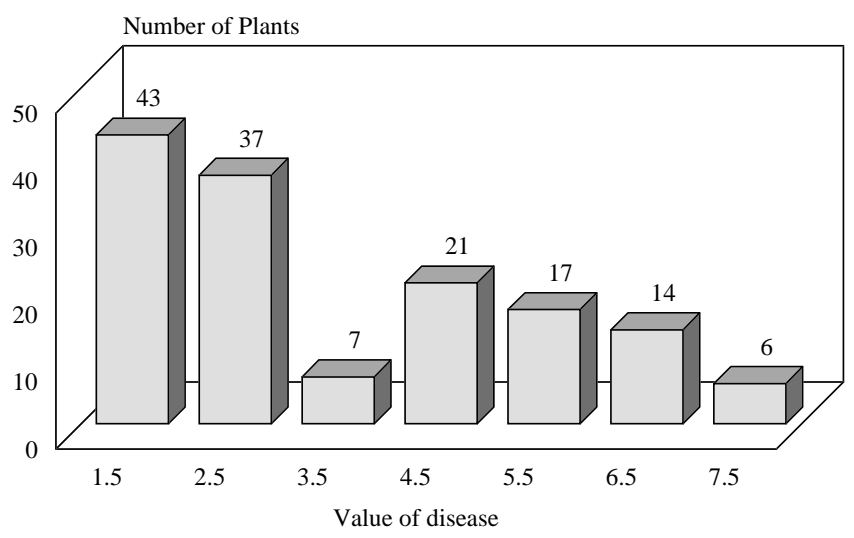

C

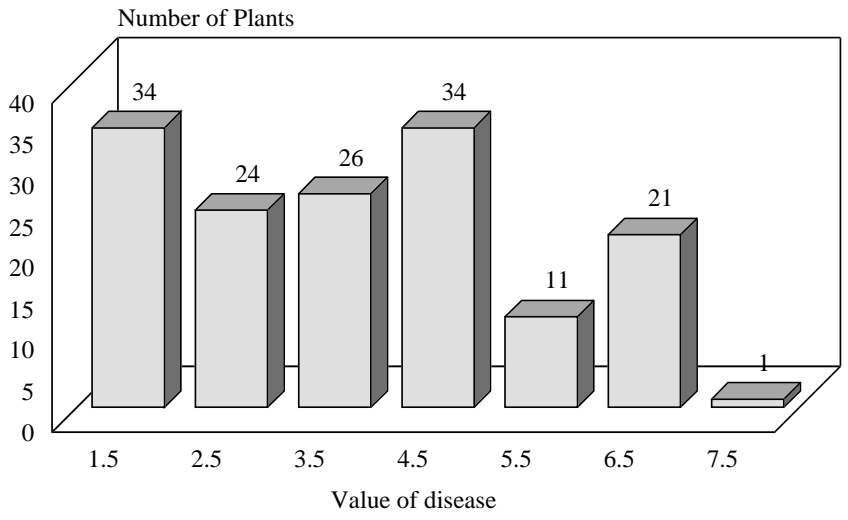

B

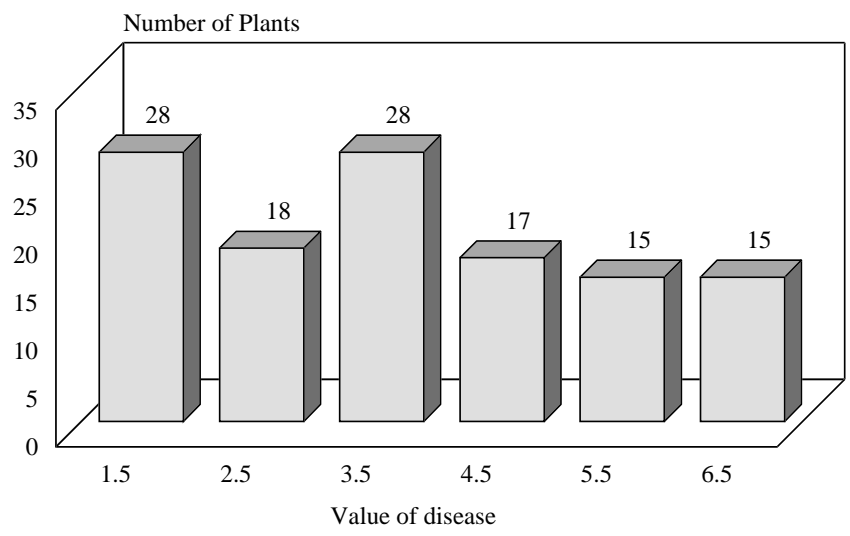

D

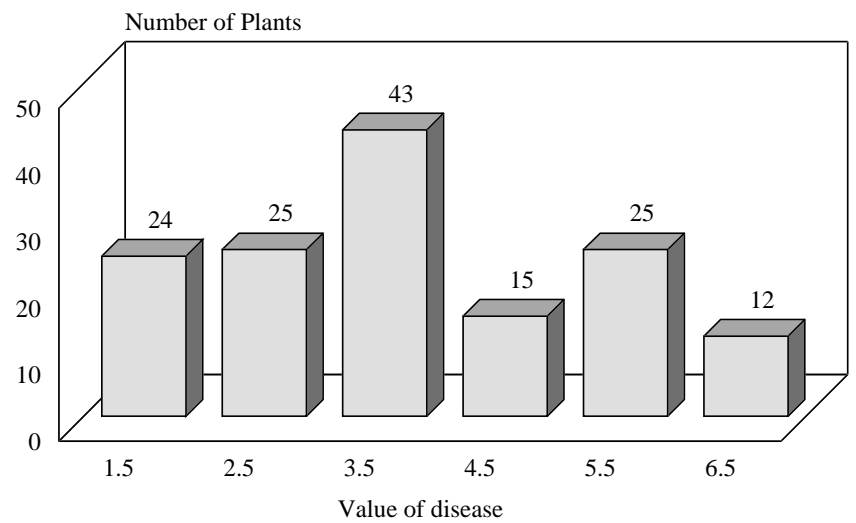

Figure 1 - Frequency distribution of disease values of Erysiphe polygoni occurrence in Phaseolus vulgaris line crosses. A and $\mathrm{B}_{\text {are }} \mathrm{F}_{2}$ and $\mathrm{F}_{2: 3}$ generations, respectively, from the Jalo $x$ ESAL 686 cross; $\mathrm{C}$ and $\mathrm{D}$ are $\mathrm{F}_{2}$ and $\mathrm{F}_{2: 3}$ generations, respectively, from the ESAL $550 \times$ ESAL 686 cross.

Table III - Number of plants in $\mathrm{F}_{2}$ and number of families in $\mathrm{F}_{2: 3}$ evaluated for reaction to Erysiphe polygoni in Phaseolus vulgaris and results of $\chi^{2}$ tests for both crosses.

\begin{tabular}{|lclrrr|}
\hline & & & \multicolumn{2}{c|}{ Reaction to pathogen } & \\
\cline { 3 - 4 } Cross & Generation & Number & Resistant & Susceptible & $\chi^{2}$ \\
\hline Jalo x ESAL 686 & $\mathrm{F}_{2}$ & Observed & 87 & 58 & \\
& & E.F. & 9 & 7 & \\
& & Expected & 81.5625 & 63.4375 & 0.8286 \\
& $\mathrm{~F}_{2: 3}$ & Observed & 74 & 47 & \\
ESAL 550 x ESAL 686 & & E.F. & 9 & 7 & \multirow{2}{*}{1.1839} \\
& $\mathrm{~F}_{2}$ & Expected & 68.0625 & 52.9375 & \\
& & Observed & 84 & 67 & \\
& & E.F. & 9 & 7 & \multirow{2}{*}{0.0237} \\
& $\mathrm{~F}_{2: 3}$ & Expected & 84.9375 & 66.0625 & \\
& & Observed & 92 & 52 & \\
& & E.F. & 9 & 7 & 3.4145 \\
\hline
\end{tabular}

${ }^{1}$ Expected frequency. 
In spite of the discrepancy in the literature, one can infer that few genes are involved in the control of the trait. Heritability estimate, in the wide sense, based on the average of the $\mathrm{F}_{2.3}$ families was higher than $85 \%$, and that obtained by the regression $\mathrm{F}_{2}$ plant $/ \mathrm{F}_{2: 3}$ family was higher than 0.66 , reinforcing the observation that genetic control is due to few genes. So, success in selection for resistant plants and/or families in segregating populations is expected.

\section{RESUMO}

Para estudar o controle genético da resistência ao oídio (Erysiphe polygoni) no feijoeiro foram utilizadas as populações segregantes dos cruzamentos Jalo x ESAL 686 e ESAL 550 x ESAL 686. As plantas $F_{2}$ desses cruzamentos, juntamente com os parentais, foram inoculadas e avaliadas utilizando-se uma escala de notas de 1 (planta sem sintoma) a 9 (planta completamente infectada). As plantas $\mathrm{F}_{2}$ foram colhidas individualmente e obtidas as famílias $\mathrm{F}_{2 \cdot 3}$. Essas famílias foram avaliadas nos delineamentos látice simples 11 x 11 e 12 × 12 para os cruzamentos Jalo x ESAL 686 e ESAL $550 \times$ ESAL 686, respectivamente, utilizando-se a mesma escala de notas da geração $\mathrm{F}_{2}$. As segregações observadas nas plantas $\mathrm{F}_{2}$ e nas famílias $\mathrm{F}_{2: 3}$ indicam que no controle genético estão envolvidos dois genes, sendo este um caso de epistasia recessiva dupla. O coeficiente de regressão linear (b) entre a planta $\mathrm{F}_{2}$ e sua família $\mathrm{F}_{2: 3}$ mostrou que o caráter possui alta herdabilidade.

\section{REFERENCES}

Arriel, E.F., Santos, J.B. dos and Ramalho, M.A.P. (1991). Efeito do oídio no rendimento da cultura do feijão. Pesq. Agrop. Bras. 26: 849-852.

Bett, K.E. and Michaels, T.E. (1995). A two-gene model for powdery mildew resistance in common bean. Ann. Rep. Bean Improv. Cooper.
38: 145-146.

Dundas, B. (1936). Inheritance of resistance to powdery mildew in beans. Hilgardia 10: 241-253.

Nyquist, W.E. (1991). Estimation of heritability and prediction of selection response in plant populations. Crit. Rev. Plant Sci. 10: 337-345.

Ometto, J.C. (1981). Bioclimatologia Vegetal. Agronômica Ceres, São Paulo.

Ramalho, M.A.P., Santos, J.B. dos and Zimmerman, M.J. de O. (1993). Genética Quantitativa em Plantas Autógamas. Aplicações ao Melhoramento do Feijoeiro. Universidade Federal de Goiás, Goiânia.

Ramalho, M.A.P., Santos, J.B. dos and Pinto, C.A.B.P. (1994). Genética na Agropecuária. Globo, São Paulo.

Rava, C.A. and Sartorato, A. (1993). Eficiência de fungicidas no controle do oídio (Erysiphe polygoni) do feijoeiro comum. Summa Phytopathol. 19: 30 .

Rezende, V.F., Ramalho, M.A.P. and Abreu, A. de F.B. (1996). Comportamento de linhagens de feijão com relação ao nível de resistência ao oídio. In: V Reunião Nacional de Pesquisa de Feijão, Goiânia, GO, pp. 329-331.

Sartorato, A. and Rava, C.A. (1994). Principais Doenças do Feijoeiro Comum e seu Controle. EMBRAPA - SPI, Brasília, DF (EMBRAPA - CNPAF. Documentos, 50).

Sartorato, A., Rava, C.A. and Yokoyama, M. (1983). Principais Doenças e Pragas do Feijoeiro Comum no Brasil. EMBRAPA - SPI, Goiânia, GO (EMBRAPA - CNPAF. Documentos, 5).

Sartorato, A., Rava, C.A. and Costa, J.G.C. (1993). Resistência do feijoeiro comum ao oídio (Erysiphe polygoni): resultados preliminares. In: $I V$ Reunião Nacional de Pesquisa de Feijão, Londrina, PR, Resumos, 37.

Schwartz, H.F., Katherman, M.J. and Thung, M.D.T. (1981). Yield response and resistance of dry beans to powdery mildew in Colombia. Plant Dis. Rep. 65: 737-738.

Singh, S.P. and Gutierrez, J.A. (1984). Geographical distribution of the $\mathrm{DL}_{1}$ and $\mathrm{DL}_{2}$ genes causing hybrid dwarfism in Phaseolus vulgaris L., their association with seed size, and their significance to breeding. Euphytica 33: 337-345.

Vieira, A.L., Ramalho, M.A.P. and Santos, J.B. dos (1989). Crossing incompatibility in some bean cultivars utilized in Brazil. Rev. Bras. Gen. 12: 169-171.

(Received December 10, 1997) 